2. TO: (Receiving Organization) DISTRIBUTION

5. Proj./Prog./Dept./Div.:

VAPOR/AS/SPECIAL/ANALYTICAL/ SUPPORT

8. Originator Remarks:

SST-241-S-102 SAMPLING USING THE VAPOR SAMPLING SYSTEM

3. From: (Originating organization)

SPECIAL ANALYTICAL. SUPPORT

$8 C 530$

6. Design Authority/ Design Agent/Cog.

Engr : :

RICKY MAHON 3-7437

11. Receiver Remarks

11A. Design Basel ine Document?

[] Yes

[X] No
4. Related EDT No.:

N/A

7. Purchase Order No.:

$N / A$

9. Equip./Component No.:

$N / A$

10. Systen/Bldg./Facility:

$622 \mathrm{G}$

12. Major Assm. Dwg. No.:

$N / A$

13. Permit/Permit Application No.: N/A

14. Required Response Date:

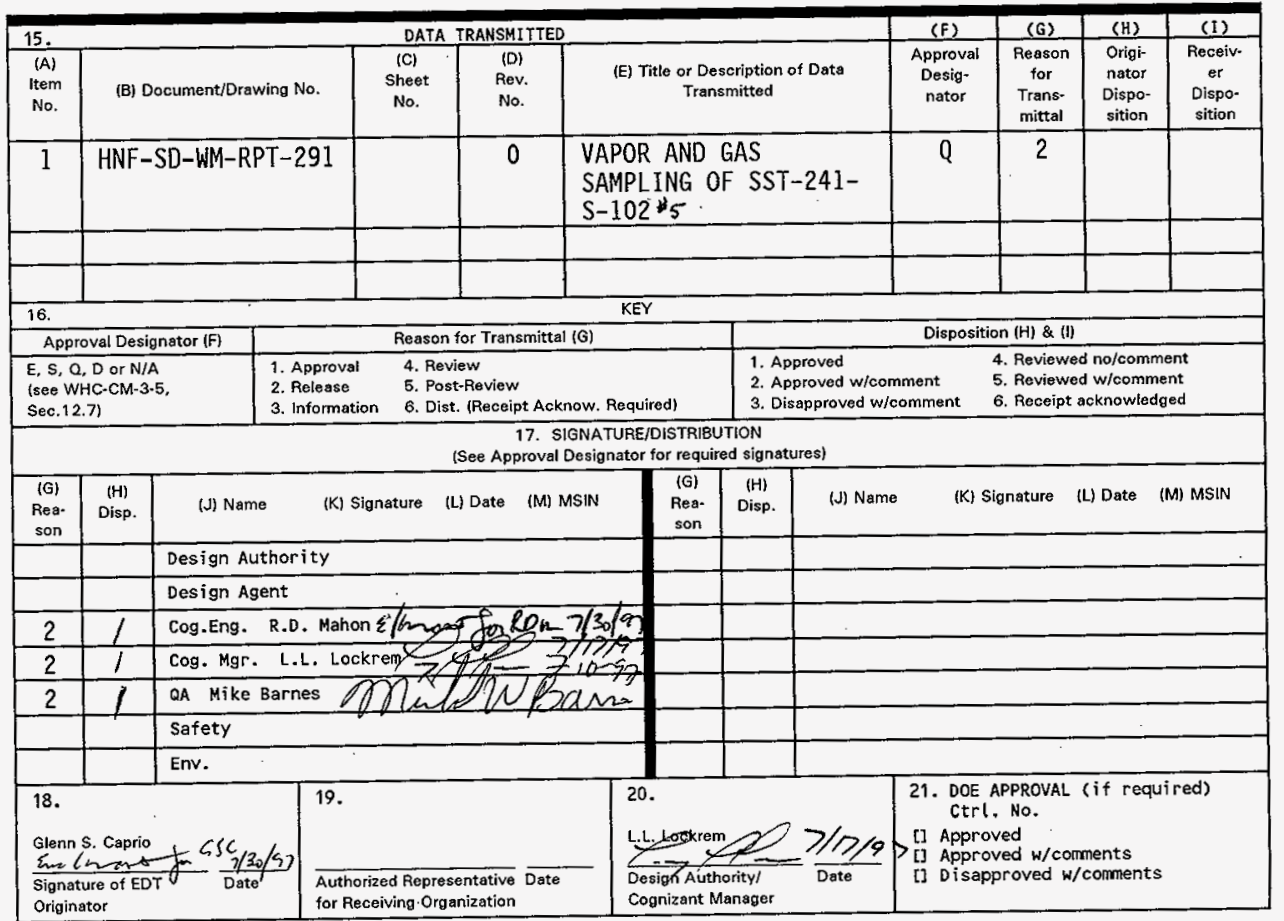




\section{VAPOR AND GAS SAMPLING OF SINGLE-SHELL TANK 241-S-102 USING the in Situ Vapor Sampling System}

\section{G.S. Caprio}

SGN Eurisys Services Company, Richland, WA 99352

U.S. Department of Energy Contract DE-AC06-96RL13200

EDT/ECN: 621405

Org Code: $8 \mathrm{C} 530$

B\&R Code: EW3120074
UC: 2070

Charge Code: E62000

Total Pages: 31

Key Words: 241-S-102, VSS, SUMMA ${ }^{\text {TM }}$, TST, SORBENT, TANK

Abstract: THIS DOCUMENT PRESENTS SAMPLING DATA RESULTING FROM THE FEBRUARY 11,1997 SAMPLING OF SST 241-S-102( $\left.{ }^{*} S\right)$

TRADEMARK DISCLAIMER. Reference herein to any specific comercial product, process, or service by trade name, trademark, manufacturer, or otherwise, does not necessarily constitute or imply its endorsement, recommendation, or favoring by the United states Government or any agency thereof or $i$ ts contractors or subcontractors.

Printed in the United States of America. To obtain copies of this document, contact: Document Control Services, P.0. Box 950, Mailstop H6-08, Richland WA 99352, Phone (509) 372-2420; Fax (509) 376-4989.
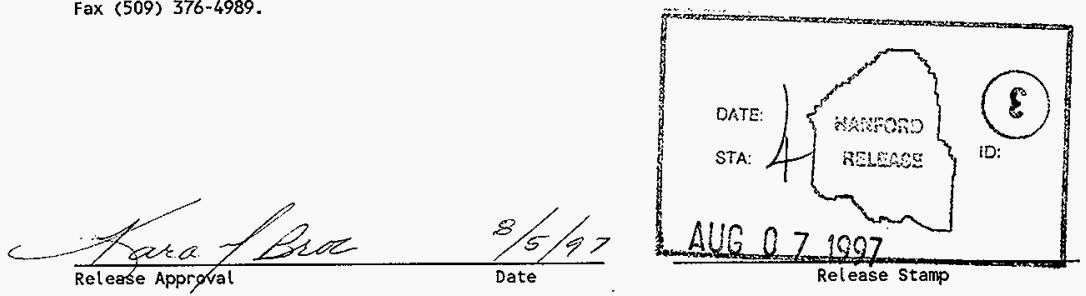
HNF - SD-WM-RPT-291， Rev. O

\section{APRROVALS}

Document title:

Vapor and Gas Sampling of Single-Shell Tank 241-S-102

(\#5) Using the Vapor Sampling System

Approved by:

G. S. Caprio, Field Scientist

Date

Vapor Sampling Project

Special Analytical Studies

Approved by:

R. D. Mahon, Project Lead

Date

Vapor Sampling Project

Special Analytical studies

Approved by:

Csmeed for Lllootsem

I. I. Lockrem, Manager

Special Analytical Studies

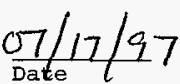


CONTENTS

$1.0 \mathrm{SCOPE}$. . . . . . . . . . . . . . . . . . . . . . . . . . I

2.0 SAMPLING EQUIPMENT DESCRIPTION . . . . . . . . . . . . . . . . . . . . 1

2.1 VAPOR SAMPLING SYSTEM . . . . . . . . . . . . . . . . . . . . . . 1

3.0 SAMPIING EVENT DESCRIPTION . . . . . . . . . . . . . . . . . . . 2

3.1 SPECIFICATIONS . . . . . . . . . . . . . . . . . . 2

3.2 OPERATIONS AND SAMPLING PERSONNEL . . . . . . . . . . . . . . . . . 2

3.3 INDUSTRIAI HYGIENE FIELD RESULTS . . . . . . . . . . . . . . . 3

3.4 AMBIENT CONDITIONS . . . . . . . . . . . . . . . . . . . . . . . . 3

3.5 SAMPLE COLLECTION . . . . . . . . . . . . . . . . . . . . . . . 3

3.6 FIELD GC/FID RESULTS . . . . . . . . . . . . . . . . . . . . . . . 4

3.7 RADIATION SCREENING . . . . . . . . . . . . . . . . . . . . . . 4

4.0 SAMPLE CHAIN OF CUSTODY: RECEIPT, STORAGE, AND SHIPMENT . . . . . 5

5.0 QUALITY ASSURANCE AND CONTROLS . . . . . . . . . . . . . . . . . . . . . 6

5.1 VAPOR SAMPLING SYSTEM CLEANING . . . . . . . . . . . . . . . . 6

5.3 BLANK SAMPLES

6.0 ANOMALIES . . . . . . . . . . . . . . . . . . . . . . . . . . . . . 8

7.0 REgERENCES . . . . . . . . . . . . . . . . . . . . . . . . 8

\section{APPENDICES}

SAMPLE LOG SHEETS . . . . . . . . . . . . . . . . . . . . . A-1

AMBIENT CONDITIONS . . . . . . . . . . . . . . . . . . . . . . B-I

CHAIN-OF-CUSTODY FORMS . . . . . . . . . . . . . . . . . . . C-1 
HNF-SD-WM-RPT-291，ReV. 0

\section{IIST OF TABLES}

1. Radionuclide Analysis Results. . . . . . . . . . . . . . . . . . . . 5

2. Pacific Northwest National Laboratory Samples . . . . . . . . . . . . 6

3. Calibration Data . . . . . . . . . . . . . . . . . . . . . . . . . 7 
HNF-SD-WM-RPT-291, Rev . 0

\section{IIST OF TERMS}

CGI
COC
DOT
GC/FID
GEA
ISVS
$\mathrm{NH}_{3}$
$\mathrm{H}_{2} \mathrm{O}$
OPC
OVM
PNNL
SAS
SML
SST
TCP
TEAM
TOC
TST
VSS
WHC

Combustible Gas Indicator Chain of Custody

U.S. Department of Transportation

Gas Chromatograph/Flame Ionization Detector Gamma Energy Analysis

In Situ Vapor Sampling System

Ammonia

Water vapor

Offsite Property Control

Organic Vapor Meter

Pacific Northwest National Laboratory

Special Analytical studies

Sampling and Mobile Laboratories

Single-Shell Tank

Tank Characterization Plan

Vapor Team

Total Organic Carbon

Triple Soxbent Trap

Vapor Sampling System

Westinghouse Hanford Company 
HNF -SD-WM-RPT-291， Rev. 0

This page intentionally left blank. 
HNE-SD-WM-RPT-291, Rev. 0

VAPOR AND GAS SAMPLING OF SINGLE-SHELL TANK 241-S-102

USING THE VAPOR SAMPLING SYSTEM

\subsection{SCOPE}

The Vapor Issue Resolution Program tasked the Vapor Team (the team) to collect representative headspace samples from Hanford Site single-shell tank (SST) 241-S-102. This document presents sampling data resulting from the February 11, 1997 sampling of SST 241-S-102. Analytical results will be presented in separate reports issued by the Pacific Northwest National Laboratory which supplied and analyzed the sample media.

This is the last in a series of temporal sapling events on SST 241-S-102. The strategy of temporal sampling is to measure the compositional changes of the waste tank headspace as related to seasonal effects and gradual changes of waste chemistry.

\subsection{SAMPLING EOUIPMENT DESCRIPTION}

\subsection{VAPOR SAMPLING SYSTEM}

The team, consisting of Special Analytical Studies (SAS) personnel, used the vapor sampling system (VSS) to collect representative samples of the air, gases, and vapors from the headspace of SST 241-S-102 with sorbent traps and SUMMA ${ }^{1}$ canisters on February 11, 1997. Mahon et al. (1994) describes in detail the VSS, its performance, and its operation.

The VSS comprises a mobile laboratory connected to the vapor space of the waste tank by stainless steel transfer tubing. A vacuum pump draws sample vapor from the tank headspace through the transfer tubing and into the sampling manifold. Electrically activated, pneumatically actuated, valves direct sample flow within the VSS. Instrumentation housed in the mobile laboratory monitors and controls system temperature, monitors absolute and differential system pressure, meters and controls vapor mass flow, and monitors total organic carbon (TOC) content of sample vapor using a gas chromatograph/flame ionization detector (GC/FID).

A key feature of the VSS is its use of heated transfer tubing and a heated sampling manifold. Maintaining the system at an elevated and controlled temperature prevents vapor condensation and reduces vapor adsorption on surfaces exposed to sample vapor. Mahon et al. (1994) describes various tests and observations that indicate the VSS sample transfer efficiency is consistently high.

Highly accurate mass flow controllers control the sample vapor flow rate through the sorbent traps at the sorbent trap station. The controllers FICV-1 through FICV-9 are mounted on top of the sorbent station between the inlet and outlet valves of their respective sampling ports. While controllers FICV-10 and FICV-11 are located downstream of the sorbent trap station and the in-line driers, which remove moisture from the sample vapor before it is metered.

The VSS is equipped with a Hewlett Packard 5890 Series II gas chromatograph (GC) which is equipped with a flame-ionization detector (FID), $1 \mathrm{~mL}$ sample loop, 10 port injection valve, 2 meter chromatographic column, programmable oven, and a portable computer loaded with the HP-Chemstation software providing computer control. The oven is programmed to heat from $50^{\circ} \mathrm{C}$ to $270^{\circ} \mathrm{C}$ at a rate of $70^{\circ} \mathrm{C}$ per minute. Helium is the carrier gas, air and hydrogen the

${ }^{1}$ SUMMA is a registered trademark of Molectrics, Inc., Cleveland, Ohio. 
combustion gases, and nitrogen the make-up gas. The GC is plumbed to accept sample from the VSS manifold to the sample loop. After the sample is transferred into the sample loop and reaches equilibrium, the run is initiated by the operator from the computer. HP-Chemstation software activates the 10 port valve which transfers a sample from the sample loop to the HP-5 column. The column is $2 \mathrm{~m}$ long and has an inside diameter of $0.25 \mathrm{~mm}$ wich is coated with a chemically bonded phenyl methyl silicone layer to minimize sample intereference. The sample passes through the column to the FID which generates a TOC signal for that sample. The data is then transmitted to the computer where it is stored for future retrieval and analysis. The GC/FID is configured to confirm sampling system cleanliness, and to quantitatively estimate TOC concentration in ambient air and tank vapor samples in real time.

The system is multi-point calibrated at the weather station on a as available basis and last performed January 1995. The GC/FID has displayed a high degree of stability over a period of months. For further details, see section 3.6 , Field GC/FID Results.

Sorbent trap samples, pencil-size stainless steel or glass tubes that contain vapor-adsorbing media, are collected at the sorbent trap station of the sampling manifold. The rate and duration of flow, as specified by the analytical laboratory providing the sample media, determines the total volume of vapor to be passed through the tube. Virtualiy all the target analytes are trapped in the tube by the adsorbing media. Analyte concentration in the tank vapor can then be ascertained from the sorbent media analysis knowing the total volume of vapor which passed through the sorbent trap.

SUMMA" canisters, stainless steel vessels with their internal surfaces chemically passivated by the SUMMA" process to minimize adsorption of gases and vapors are used to sample tank vapor from the SUMMA sampling station on the sampling manifold. The precleaned and evacuated SUMMA canisters are filled with sample vapor by opening a manually operated valve, which is then shut after pressure equilibration to seal the sample inside. SUMMA canisters allow a 6 liter sample to be transported to an analytical laboratory.

\subsection{SAMPLING EVENT DESCRIPTION}

\subsection{SPECIFICATIONS}

The Vapor Issue Resolution Program specifies sampling requirements in WHC-SD-WM-TP-522 Rev OD, Vapor SampIing and Analysis Plan (Buckley 1997). The Sampling and Analysis Plan also specifies the types and number of samples to be collected, flow rates, and durations. These key sampling parameters are summarized on the sample log sheets in Appendix A. In addition to the sample log sheets, checksheets for each individual sample help ensure correct sampling procedures. The team retains these documents in the project file. This sample event's project-specific number is V7-006.

\subsection{OPERATIONS AND SAMPLING PERSONNEI,}

Steve Carter was the Tank Farm Operations person-in-charge. The team members included:

R. D. Mahon, VSS Lead Scientist

E. S. Mast, Field Scientist

The VSS was set up at SST 241-S-102 on February 10, 1997 and was allowed to warm up overnight. Sampling began at about 09:00 a.m. on February 11, 1997, and was completed shortly After 11:30 p.m. the same day. 


\subsection{INDUSTRIAL HYGIENE FIFLD RESULTS}

Prior to hooking up to SST 241-S-102, an industrial hygiene technician field tested tank vapors. The technician purged the instrument/vent header for 5 minutes and then field measured vapor stream contents using a combustible gas indicator (CGI) and an organic vapor meter (OVM). The measurements were verbally reported, LEL $2 \%, \mathrm{NH}_{3} 600 \mathrm{ppm}, \mathrm{O}_{2} 20.7 \%$, and TOC $33 \mathrm{ppm}$.

\subsection{AMBIENT CONDITIONS}

The weather the day of the sampling event, February 11, 1997 was cold with a light wind. Graphs of ambient temperatures and pressures taken at the Hanford Meteorological station, which is about 2.5 miles north east of $\mathrm{S}-\mathrm{Farm}$, are provided in Appendix B.

\subsection{SAMPLE COLLECTION}

The hot-water-jacketed sampling probe was located in Risex 7 of SST 241-S-102. The probe length, from the sample inlet to the top of the riser flange, was 6.1 meters.

All zones of the VSS were heated to $60^{\circ} \mathrm{C}$ during setup of the VSS at SST 241-S-102 on February 10, 1997. The team stabilized the vss temperature zones by $8: 30 \mathrm{a.m}$. on February 11, 1997, and the system was ready to collect samples. Measured according to the VSS operating procedure, the pressure and temperature of SST 241-S-102 were 998 mbar (749.0 torr) and $22.5{ }^{\circ} \mathrm{C}$, respectively. The sample log sheets (Appendix A) provide a complete chronology of the sample event including start and end times, flow rates, volumes, and specific sample identifiers.

Approximately 20 hours before the first samples were collected, the team began heating the VSS transfer tubing and sampling manifold. During this warmup period, the team began a purge of all vapor transfer tubing and the sampling manifold with ambient air. Prior to sampling tank vapors on February 11, 1997, the team collected two SUMMA canister samples of ambient air, one manually 10 meters upwind of the VSS connection with SST 241-S-102, and the other using the VSS sampling manifold. The former was collected to establish background levels of trace organic vapors, and the latter was collected to establish the cleanliness of the sampling manifold. The flow meter's precision was verified prior to sampling. The Grubbs test for outliers was used to determine if a meter was operating outside of its acceptance range.

A leak check of the VSS sampling manifold and transfer tubing was performed. The system was evacuated to 272.5 mbar (204.4 torr) and leakage of ambient air into the system was observed by monitoring system pressure for 15 minutes. Leakage resulted in an increase of $4.2 \mathrm{mbar}$ ( 3.2 torr) in system pressure during the 15 minute test.

The sampling valve was opened and the VSS was purged with sample vapor from SST 241-S-102 for 30 minutes at a total flow rate of $4.38 \mathrm{~L} / \mathrm{min}$. This purge was performed to flush ambient air from the system and saturate the system's active adsorption sites. Because the volume of transfer tubing and the sampling manifold upstream of the sampling devices is estimated to be no more than $10 \mathrm{I}$, this purge provided about 13.1 air turnovers in the system.

One analytical laboratory provided sample media. PNNL provided SUMMA" canisters, sorbent traps for organic vapors, ammonia $\left(\mathrm{NH}_{3}\right)$ and water vapor $\left(\mathrm{H}_{2} \mathrm{O}\right)$, and TST sorbent traps. 


\subsection{FIELD GC/FID RESULTS}

The GC\FID was not used in the sampling of tank 241-S-102 due to the time required to get approval by the new flammability committee for use in field sampling. Per the Sampling and Analysis Plan sampling continued without the GC\FID.

\subsection{RADIATION SCREENING}

Samples are unconditionally released from the SST farm in accordance with 19965-3E100-RSP-02 Rev 01, Release Survey of Vapor Sampling Equipment (WHC 1996). Radiological screening results are used to determine (1) if the samples must be shipped as radioactive or nonradioactive in accordance with U.S. Department of Transportation (DOT) regulations and (2) if the samples meet the laboratory acceptance criteria.

The DOT limits for shipping a nonradioactive sample are 2000 combined pCi/g of beta-gamma activity and alpha activity. Samples exceeding these DoT limits may be shipped as radioactive material if the samples do not exceed the following laboratory acceptance cxitexia:

PNNL: $\quad$ Beta-gamma activity $<400 \mathrm{pCi} / \mathrm{g}$ of sample media. Alpha activity $<100 \mathrm{pCi} / \mathrm{g}$ of sample media.

To protect the sampling manifold and sampling devices from radioactive particulates, all sample vapor for the Eebruary 11, 1997, SST 241-S-102 vapor sampling event was drawn through a series of four filters placed upstream of the sampling manifold. These four filters were in place any time tank vapors were flowing through the system. When sampling was complete, the filters were removed and assigned unique sample identifiers. All four filters were submitted to Waste Sampling Characterization Facility Laboratory for total alpha, total beta, and gamma energy analysis (GEA). The filter closest to the sampling manifold was analyzed to determine if the samples met DOT shipping criteria and laboratory acceptance criteria. Moisture from the tank vapors was collected in a silica gel trap through one of the sorbent station ports and analyzed for tritiated water. SST 241-S-102 filter and silica gel analysis results are show in Table 1 . The vapor team scientists use the activity results in Table 1 to calculate pCi/g of sample media. The team maintains this information in the project-specific file. The results in Table 1 indicate that the samples collected from SST 241-S-102 met the laboratory acceptance criteria and the DOT definition of a nonradioactive shipment. 
HNF - SD -WM-RPT-291, Rev . 0

Table 1. Radionuclide Analysis Results.

\begin{tabular}{|c|c|c|c|}
\hline Filtex & $\begin{array}{l}\text { Sample } \\
\text { Identifier }\end{array}$ & $\begin{array}{l}\text { Activity Results } \\
\text { (pCi/sample) }\end{array}$ & $\begin{array}{c}\text { Activity } \\
\text { (pCi/L of tank gas) }\end{array}$ \\
\hline $\begin{array}{l}\text { Upstream filter } \\
\text { (box) }\end{array}$ & V7006-A21.OU1 & $\begin{array}{l}\text { Total Alpha }=120 \\
\text { Total Beta }=230 \\
\text { GEA }=\mathrm{Cs}_{137} 11.2\end{array}$ & $\begin{array}{l}=0.59 \\
=1.12 \\
=0.05\end{array}$ \\
\hline $\begin{array}{l}\text { Downstream } \\
\text { filter (box) }\end{array}$ & V7006-A22.OD1 & $\begin{array}{l}\text { Total Alpha }=<0.12 \\
\text { Total Beta }=1.60 \\
\text { GEA = <detectable }\end{array}$ & $\begin{array}{c}=<\text { detectable } \\
=0.01 \\
=<\text { detectable }\end{array}$ \\
\hline $\begin{array}{l}\text { Upstream filter } \\
\text { (Vss) }\end{array}$ & V7006-A23.OU2 & $\begin{array}{l}\text { Total Alpha }=<0.37 \\
\text { Total Beta }=3.40 \\
\text { GEA }=\text { <detectable }\end{array}$ & $\begin{array}{c}=\text { <detectable } \\
=0.02 \\
=<\text { detectable }\end{array}$ \\
\hline $\begin{array}{l}\text { Downstream } \\
\text { filter (VSS) }\end{array}$ & V7006-A24.OD2 & $\begin{array}{l}\text { Total Alpha }=<0.49 \\
\text { Total Beta }=0.81 \\
\text { GEA = <detectable }\end{array}$ & $\begin{aligned}= & \text { <detectable } \\
& =0.00 \\
= & \text { <detectable }\end{aligned}$ \\
\hline Tritium trap & V7006-A03.OT1 & Total activity $=16$ & $=16^{\circ}$ \\
\hline
\end{tabular}

NOTES:

The samples are nonradioactive. These results were evaluated against laboratory acceptance criteria and DOT limits.

"All less than (<) values represent the minimum detection limits at Laboratory $222-\mathrm{S}$.

Numbers based on an approximation of the total volume of tank vapor through the filters. Appendix $A$ and the sample checksheets were used to estimate a total flow through the vSS of $205.0 \mathrm{~L}$.

Number is calculated using a total volume of $1 \mathrm{~L}$ passing through the tritium trap.

\subsection{SAMPLE CHAIN OF CUSTODY: RECEIPT, STORAGE, AND SHIPMENT}

All sorbent trains, TSTs, and SUMMA" canisters received fxom RNNL were transported in a government vehicle to a custody locked storage area maintained by SAS. Sorbent trains, tubes and traps were maintained at $4 \pm 2$ ${ }^{\circ} \mathrm{C}$ in a refrigeration unit in the locked storage area.

On February 14, 1997, all sorbent tubes, TSTs, and SUMMA" canisters were transported by government vehicle to PNNL and delivered to J. A. Edwards. Table 2 lists the sample identifiers, types, and COC form numbers.

From the time that samples are received by SAS until they are shipped back to the analytical laboratory, all COCs are maintained by SAS in accordance with WHC-IP-1127-1.3, Chain-of-Custody/Special Analysis Request for RCRA and CERCLA Protocol Samples (WHC 1995a). Copies of the completed COC forms for this sampling event are included in Appendix $\mathrm{C}$. 
HNF-SD-WM-RPT-291, Rev. 0

Table 2. Pacific Northwest National Laboratory Samples.

\begin{tabular}{|c|c|c|}
\hline Sample Identifier & Sample Type & COC Number \\
\hline $\mathrm{V7006-A01.066}$ & Ambient upwind SUMMA" & 100658 \\
\hline $\mathrm{V} 7006-\mathrm{A} 02.089$ & Ambient SUMMA" (VSS) & 100658 \\
\hline V7006-A04.142 & SUMMA. & 100658 \\
\hline V7006-A05. 167 & SUMMA" & 100658 \\
\hline $\mathrm{V} 7006-\mathrm{A} 06.169$ & SUTMMA $^{\mathrm{nk}}$ & 100658 \\
\hline V7001-A07.40R & $\mathrm{NH}_{3} / \mathrm{H}_{2} \mathrm{O}$ sorbent & 100660 \\
\hline V7006-A08.4IR & $\mathrm{NH}_{3} / \mathrm{H}_{2} \mathrm{O}$ sorbent & 100660 \\
\hline $\mathrm{V7006-A09.42R}$ & $\mathrm{NO}_{3} / \mathrm{H}_{2} \mathrm{O}$ sorbent & 100660 \\
\hline 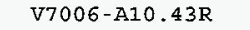 & $\mathrm{NH}_{3} / \mathrm{H}_{2} \mathrm{O}$ sorbent & 100660 \\
\hline V7006-A15.44R & $\mathrm{NH}_{3} / \mathrm{H}_{2} \mathrm{O}$ field blank & 100660 \\
\hline $\mathrm{V} 7006-\mathrm{A} 16.45 \mathrm{R}$ & $\mathrm{NH}_{3} / \mathrm{H}_{2} \mathrm{O}$ field blank & 100660 \\
\hline V7006-A11.1115 & TST & 100659 \\
\hline V7006-A12.1116 & TST & 1006459 \\
\hline V7006-A13.1117 & TST & 100659 \\
\hline V7006-A14.1118 & TST & 100659 \\
\hline V7006-A17. 1344 & TST Field Blank & 100659 \\
\hline V7006-A18.1345 & TST Field Blank & 100659 \\
\hline V7006-A19.1346 & TST Trip Blank & 100659 \\
\hline V7006-A20.1347 & TST Trip Blank & 100659 \\
\hline
\end{tabular}

\subsection{QUAIITY ASSURANCE AND CONTROLS}

\subsection{VAPOR SAMPLING SYSTEM CLEANING}

Immediately prior to sampling of SST 241-S-102, the vSS manifold and vapor sample transfer tubing was heated to $60^{\circ} \mathrm{C}$ and ambient air was purged through the system for 1200 minutes. Also, all pextinent system valves were actuated to release any contaminants that may have collected in the vss valves themselves. A SUMMA canister ambient air sample was then collected to confirm by laboratory analysis that the VSS sampling manifold was free of trace organic contaminants (or to determine which contaminants were present and at what concentration), as discussed in section 3.5. For further details, refer to Appendix E of WHC-IP-1127-4.10 (WHC 1995b) and the project-specific file located with the team. 
Table 3. Calibration Data.

\begin{tabular}{|c|c|c|c|c|}
\hline Element & $\begin{array}{c}\text { Calibration } \\
\text { Date }\end{array}$ & $\begin{array}{c}\text { Expiration } \\
\text { Date }\end{array}$ & $\begin{array}{c}\text { WHC Standards } \\
\text { Laboratory } \\
\text { Code }\end{array}$ & $\begin{array}{c}\text { Sierra } \\
\text { Instruments, } \\
\text { Inc. Code }\end{array}$ \\
\hline FICV-1 & $8 / 16 / 96$ & $8 / 16 / 97$ & $518-28-03-012$ & 82254 \\
\hline FICV - 2 & $8 / 16 / 96$ & $8 / 16 / 97$ & $518-28-03-008$ & 78254 \\
\hline FICV-3 & $8 / 16 / 96$ & $8 / 16 / 97$ & $518-28-03-004$ & 37023 \\
\hline FICV -4 & $8 / 16 / 96$ & $8 / 16 / 97$ & $518-28-03-006$ & 44023 \\
\hline FICV -5 & $8 / 16 / 96$ & $8 / 16 / 97$ & $518-28-03-011$ & 81274 \\
\hline FICV -6 & $8 / 16 / 96$ & $8 / 16 / 97$ & $518-28-03-009$ & 80274 \\
\hline FICV -7 & $8 / 16 / 96$ & $8 / 16 / 97$ & $518-28-03-014$ & 48264 \\
\hline FICV -8 & $8 / 16 / 96$ & $8 / 16 / 97$ & $518-28-03-013$ & 47264 \\
\hline FICV -9 & $8 / 16 / 96$ & $8 / 16 / 97$ & $518-28-03-007$ & 47023 \\
\hline FICV -10 & $8 / 16 / 96$ & $8 / 16 / 97$ & $518-28-03-010$ & 81254 \\
\hline FICV-11 & $8 / 16 / 96$ & $8 / 16 / 97$ & $518-28-03-005$ & 43023 \\
\hline$P E-1$ & $6 / 27 / 96$ & $6 / 27 / 97$ & $518-80-02-005$ & $\mathrm{NA}$ \\
\hline $\mathrm{PE}-2$ & $6 / 28 / 96$ & $6 / 28 / 97$ & $518-80-02-006$ & NA \\
\hline $\mathrm{PE}-3$ & $6 / 28 / 96$ & $6 / 28 / 97$ & $518-80-02-008$ & NA \\
\hline $\mathrm{PE}-4$ & $6 / 27 / 96$ & $6 / 27 / 97$ & $518-80-02-007$ & NA \\
\hline PD - I & $6 / 26 / 96$ & $6 / 26 / 97$ & $518-80-02-004$ & NA \\
\hline PD $-26 / 26 / 96$ & $6 / 26 / 97$ & $6 / 26 / 97$ & $518-80-02-003$ & NA \\
\hline $\begin{array}{l}\text { Temperature } \\
\text { Control System }\end{array}$ & $7 / 24 / 96$ & $7 / 24 / 97$ & $\mathrm{ES}-96-00543 / \mathrm{W}$ & NA \\
\hline
\end{tabular}

\subsection{INSTRUMENT CALIBRATION}

Instruments located in the vSS are calibrated on an annual basis. VSS instrumentation calibration data, maintained in files by the team, are summarized in Table 3 . Exrors associated with the mass flow meters and totalizers were determined by the Sierra Instruments Inc. all mass flow meters were within $0.5 \%$ full scale during the SST 241-S-102 sampling event.

The flow measurements for this sampling event may have an error of 6 percent to 14 percent due to the mass flow measuring devices recalibration discrepancies. A detailed description of this discrepancy can be found in internal memo 75-820-96-028 (Trible 1996c).

\subsection{BLANK SAMPLES}

Trip blanks are samples that accompany the sample media from the point of generation through sample analysis. They are transported to the field with the sample collection media but remain unopened during the sampling event. Analysis of trip blanks is used to assess cross-contamination of sample media during field transport and storage. 
HNF-SD-WM-RPT-291，Rev. 0

Field blanks are sampling devices similar to trip blanks. They are prepared and handled in the same manner as the sampling media, but no tank vapors are drawn through them.

Spiked blanks are prepared as regular sampling media but also contain a known amount of special analyte. Tank vapors are drawn through these blanks and they are handled and analyzed just like any other sample. Analysis of the spiked blanks is used to evaluate potential sample loss during shipment or storage.

Ambient blanks are samples of ambient air collected at the sampling location. Analysis of ambient blanks is used to assess contamination that may be present in the atmosphere or in the transfer tubing or sampling manifold of the vss immediately prior to sampling operations.

Table 2 lists sample blanks used during the sampling of SST 241-S-102.

\subsection{ANOMALIES}

All samples were collected in accordance with the TCP and WHC-IP-1127-4.10, Collection of Parallel Sorbent Tube \& SUMMA Canister Samples Using the Vapor Sampling System (1995b). There were no anomalies during the Vss sampling event.

\section{0 REFERENCES}

49 CFR 100-177, 1992, "Transportation," Code of Federal Regulations, as amended.

Buckley, L. I., 1997, Vapor Sampling and Analysis Plan, WHC-SD-WM-TP-522 Rev. OD, Westinghouse Hanford Company, Richland, Washington.

Mahon, R. D., C. M. Jones, and M. S. Story, 1994 (draft), Evaluation of the Capabilities and Use of the Vapor Sampling System for Tank Headspace Sampling and Characterization, SD-WM-RPT-094, Westinghouse Hanford Company, Richland, Washington.

Trible, T. C., Viswanath, R. S., 1996C, Recommendation concerning the ISVS/VSS comparison study data with respect to calibration errors in Mass flow monitors and controllers, (internal memo 75820-96-028 to L.D. Pennington, August 28), Westinghouse Hanford Company, Richland, Washington.

WHC, 1995a, Chain-of-Custody/Special Analysis Request for RCRA and CERCLA Protocol Samples, Procedure WHC-IP-1127-1.3, Rev. 1, Westinghouse Hanford Company, Richland, washington.

WHC, 1995b, Collection of Parallel Sorbent Tube \& SUMMA Canister Samples Using the Vapor Sampling System (VSS), Procedure WHC-IP-1127-4.10, Westinghouse Hanford Company, Richland, Washington.

WHC, 1996, Release Survey of Vapor Sampling Equipment, Procedure 1996-3E100-RSP-02 Rev 01, Westinghouse Hanford Company, Richland, Washington. 
HNF-SD-WM-RPT-291，Rev . 0

This page intentionally left blank. 
HNF - SD-WM-RPT-291，Rev. 0

APPENDIX A

SAMPLE LOG SHEETS

A-1 
HNF-SD-WM-RPT-291， Rev . 0

This page intentionally left blank.

A -2 
Set up VSS (Section A)(Temperature set point $=60^{\circ} \mathrm{C}$ )

Ensure HEPA filters are installed

Ensure connection to sample probe

System status check sheet. (Verify zones are to temp)

Tank Temperature

22.5

vSs Sampling of

S-102

Date: 11 FEB 97

vss Personnel: Mahon, Mast

Trailer Personnel: None

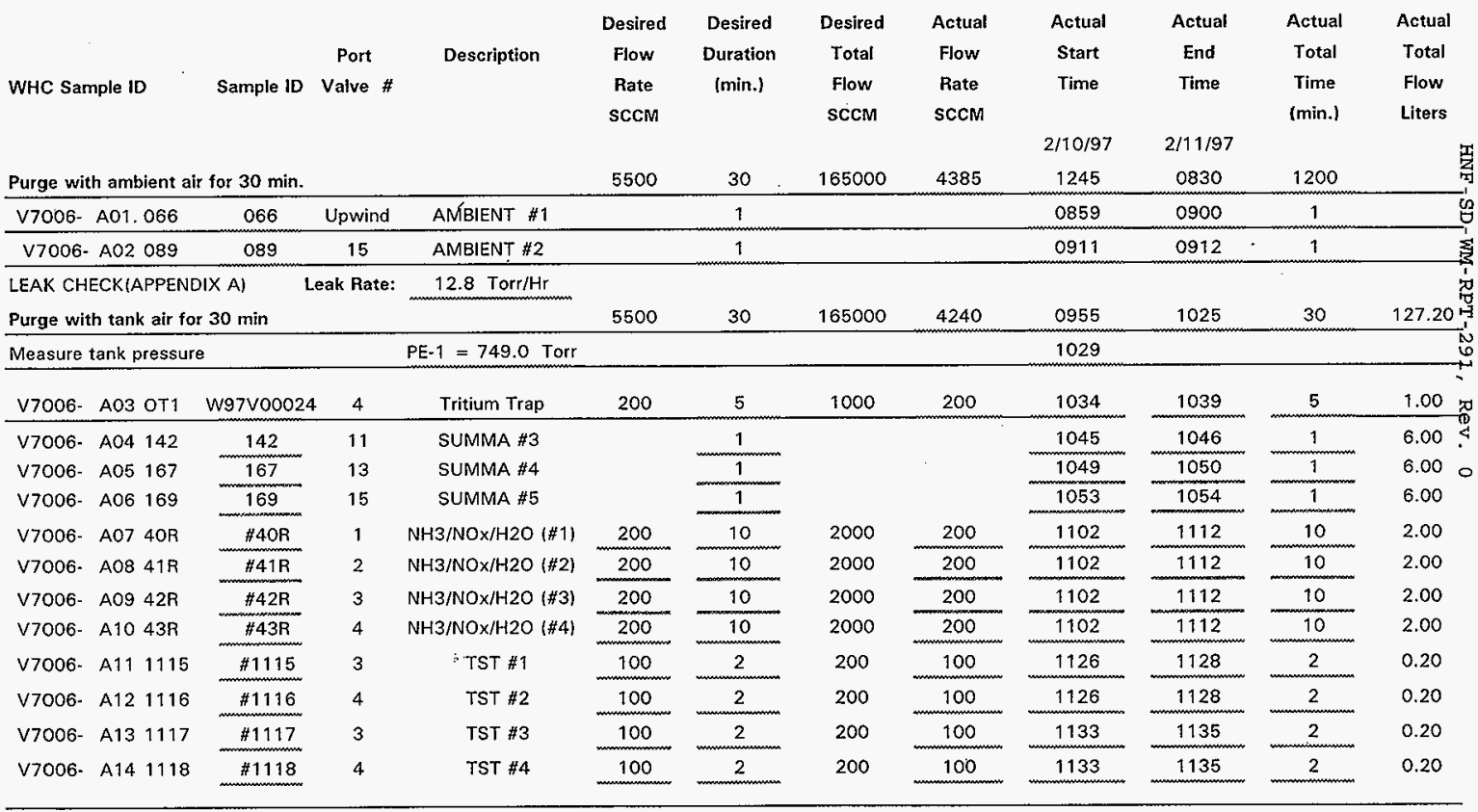




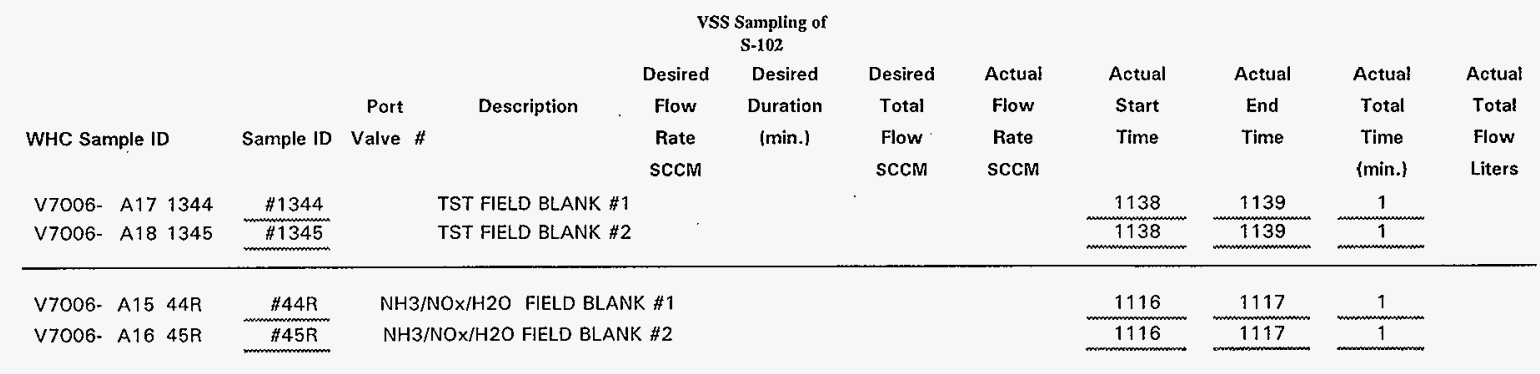

TOTAL TANK GAS USED DURING SAMPLING RUNS

\begin{tabular}{|c|c|c|c|}
\hline V7006- & A21 OU1 & W97v00020 & Upstream filter (box) \\
\hline V7006- & $A 22$ OD1 & W97V00021 & Downstream filter (box) \\
\hline V7006- & A23 OU2 & W97V00022 & Upstream filter (VSS) \\
\hline$\vee 7006-$ & A24 OD2 & W97V00023 & Downstream filter (VSS) \\
\hline
\end{tabular}

Trip Blanks (DO NOT EXPOSE)

\begin{tabular}{|c|c|c|}
\hline V7006- A19 1346 & TST\#1346 & TST TRIP \#1 \\
\hline V7006- A20 1347 & TST\#1347 & TST TRIP \#2 \\
\hline
\end{tabular}

Note: SCCM for the VSS is reported at 760 torr, $21 \mathrm{C}$

Observations / Anomalies 
HNF-SD-WM-RPT-291， Rev . 0
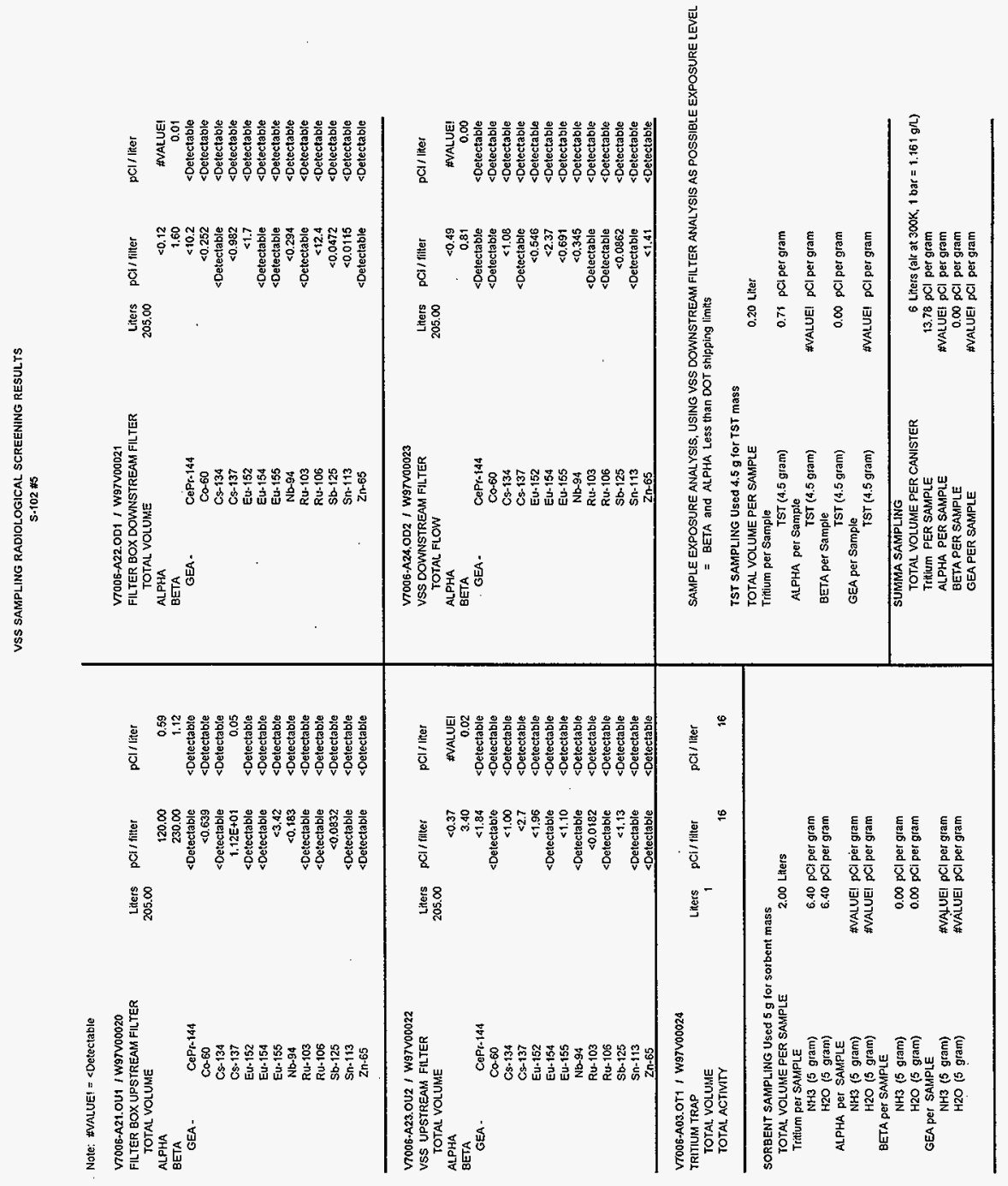

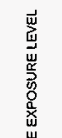

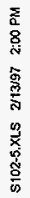


HNF - SD-WM-RPT-291， Rev . 0

This page intentionally left blank. 
HNF-SD-WM-RPT-291，Rev. 0

APPENDIX B

AMBIENT CONDITIONS

B-1 
HNE-SD-WM-RPT-291, Rev. 0

This page intentionally left blank.

B-2 
HNF-SD-WM-RPT-291，Rev. 0
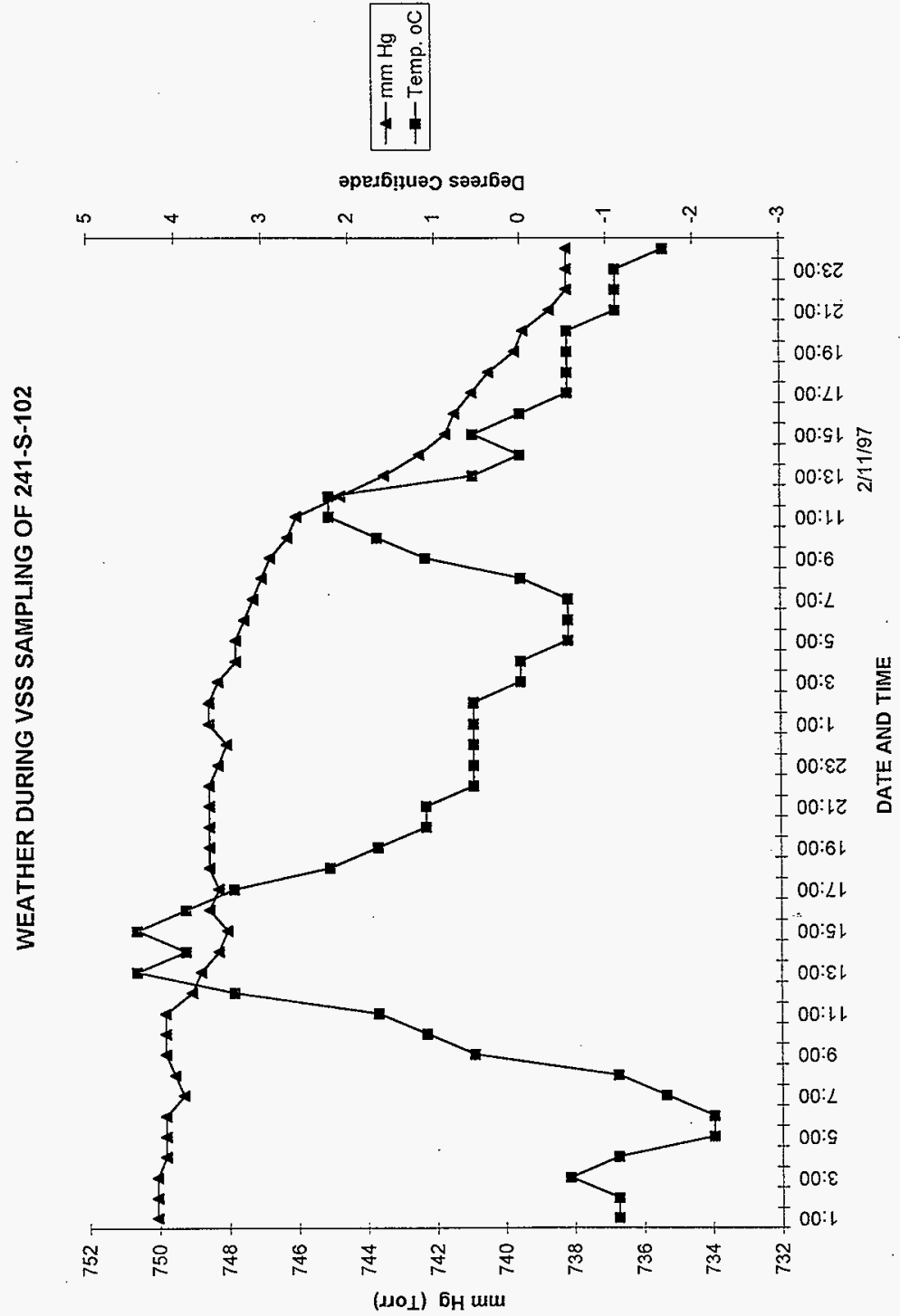
HNF-SD-WM-RPT-291， Rev . 0

This page intentionally left blank.

B- 4 
HNF-SD-WM-RPT-291， Rev. 0

APPENDIX C

CHAIN-OF - CUSTODY FORMS

C -1 
HNF-SD-WM-RPT-291， Rev . 0

This page intentionally left blank. 
HNF-SD-WM-RPT-291, Rev - 0

\begin{tabular}{|c|c|}
\hline $\begin{array}{l}\text { Battelle Pacific } \\
\text { National Northwest Lab }\end{array}$ & CHAIN \\
\hline Custody Form Initiator & J. A. Edwards - PNNL \\
\hline Company Contact & R. D. Mahon-SESC \\
\hline Project Designation/Sampling Locat & ations 200 West Tank Farm \\
\hline $\begin{array}{ll}241.5 .102 & \text { Tank } \\
\text { Temporal \#5 } & \text { Alser \# } \\
\text { Ice Chest No. } & \end{array}$ & $\begin{array}{ll}\text { Vapor Sample SAF } & \text { v7006 } \\
7 & \text { vsS }\end{array}$ \\
\hline Bill of Lading/Airbill No. & N/A \\
\hline Method of Shipment & Government Truck \\
\hline Shipped to & PNNL. \\
\hline
\end{tabular}

Sample Identification

$\begin{array}{ll}\text { V7006-A01.066 } & \text { Collect Ambient Air Sample SUMMA \#1 } \\ \text { V7006-A02.089 } & \text { Collect Ambient Air Sample SUMMA \#2 } \\ \text { V7006-A04.142 } & \text { Collect SUMMA \#3 } \\ \text { V7006-A05.167 } & \text { Collect SUMMA \#4 } \\ \text { V7006-A06.169 } & \text { Collect SUMMA \#5 }\end{array}$

Telephone (509) 373-0141

Page 85-3009/ FAX 376-0418

Telephone (509) 373-7533

Page $\quad 85-9656$ / FAX 373-3193

Collection date $\quad 2 \cdot \underline{11}-97$

Preparation date $\quad \overline{02}-06-97$

Field Logbook No. whtC $-1 /-647$ - 10

Offsite Property No. N/A

Collectors: $m+H_{\text {tor }} / m$ RSt

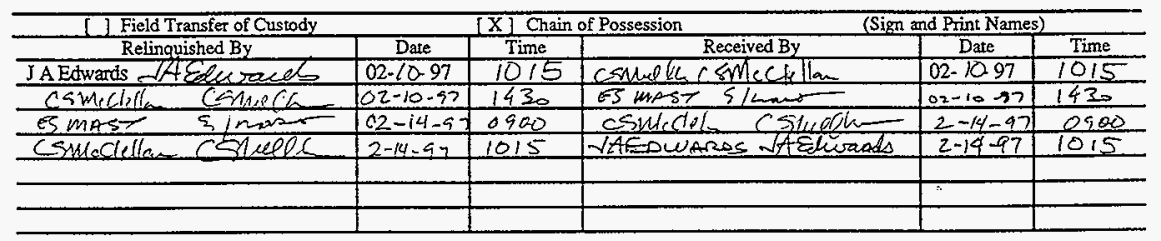

Comments:

Final Sample Disposition

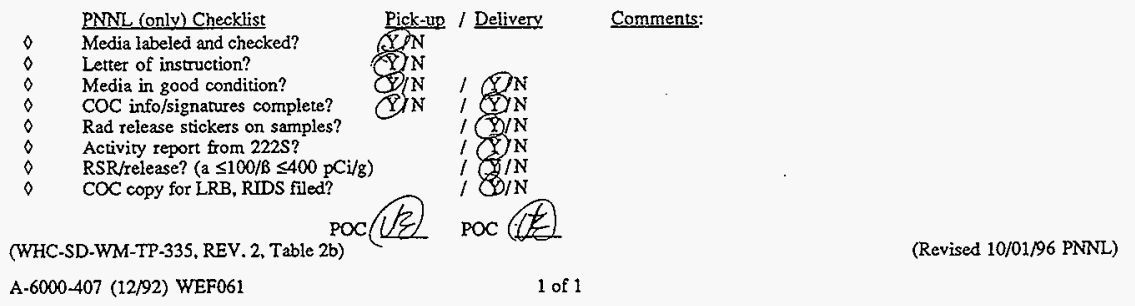




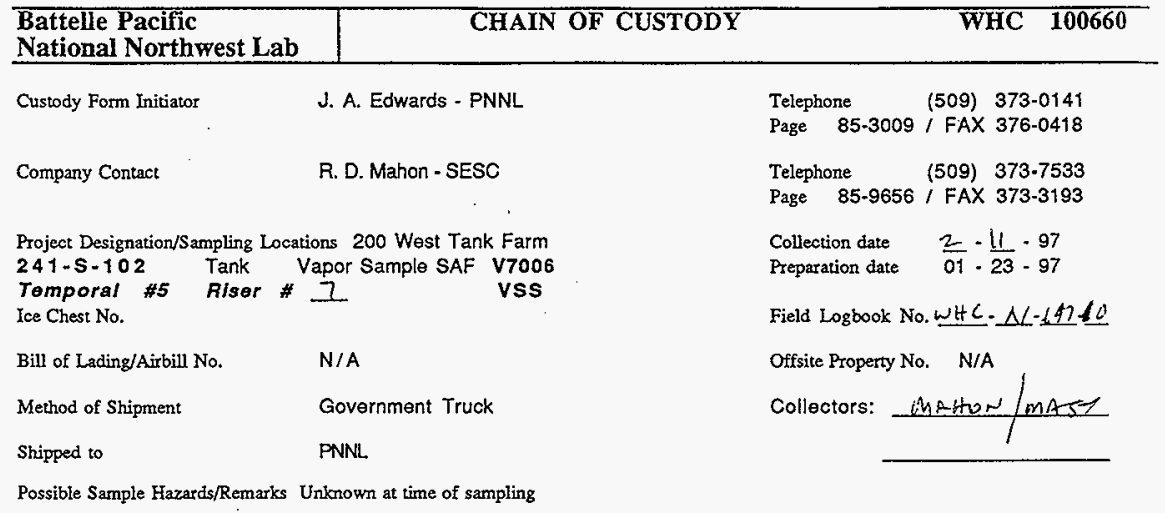

$\begin{array}{ll}\text { V7006-A07.40R } & \text { Collect } \mathrm{NH}_{3} / \mathrm{NO}_{x} / \mathrm{H}_{2} \mathrm{O} \text { Sorbent Trap } \\ \text { V7006-A08.41R } & \text { Collect } \mathrm{NH}_{3} / \mathrm{NO}_{x} / \mathrm{H}_{2} \mathrm{O} \text { Sorbent Trap } \\ \text { V7006-A09.42R } & \text { Collect } \mathrm{NH}_{3} / \mathrm{NO}_{x} / \mathrm{H}_{2} \mathrm{O} \text { Sorbent Trap } \\ \text { V7006-A10.43R } & \text { Collect } \mathrm{NH}_{3} / \mathrm{NO}_{x} / \mathrm{H}_{2} \text { O Sorbent Trap }\end{array}$

V7006 - A15 . 44R Open, close and store $\mathrm{NH}_{3} / \mathrm{NO}_{\mathrm{x}} / \mathrm{H}_{2} \mathrm{O}$ field blank \#1 V7006 - A16. 45R Open, close and store $\mathrm{NH}_{3} / \mathrm{NO}_{\mathrm{X}} / \mathrm{H}_{2} \mathrm{O}$ field blank $\# 2$
Sample Date/Time

\begin{tabular}{l|l}
\hline $2 / 11 / 57$ & 1102 \\
\hline $2 / 1 / 57$ & 1102 \\
\hline $2 / 11 / 57$ & 1102 \\
\hline $2 / 11 / 57$ & 1102 \\
\hline & \\
$2 / 11 / 57$ & 1116 \\
\hline $2 / 1197$ & 116 \\
\hline &
\end{tabular}

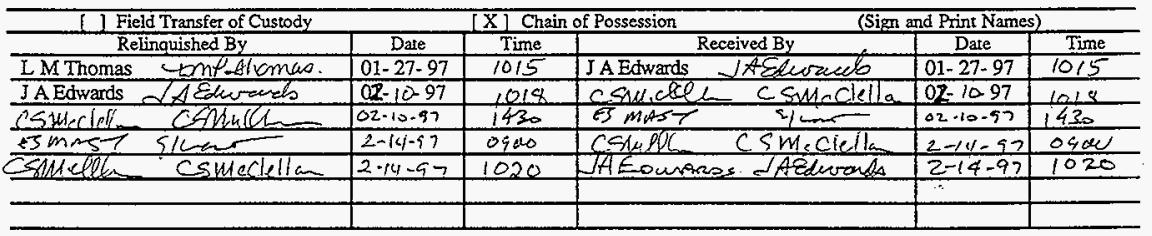

Comments:

Final Sample Disposition

BNNL (only) Checklist
Media labeled and checked?
Letter of instruction?
Media in good condicion?
COC info/signatures complete?
Rad release stickers on samples?
Activity report from 2225 ?
RSR/release? (a $\leq 100 / \mathrm{B} \leq 400 \mathrm{pCi} / \mathrm{g})$
COC copy for LRB, RDS filed?

(WHC-SD-WM-TP-335, REV. 2, Table 2b)
Comments:

(Revised 10/01/96 PNNL)
A-6000-407 (12/92) WEF061

1 of 1 


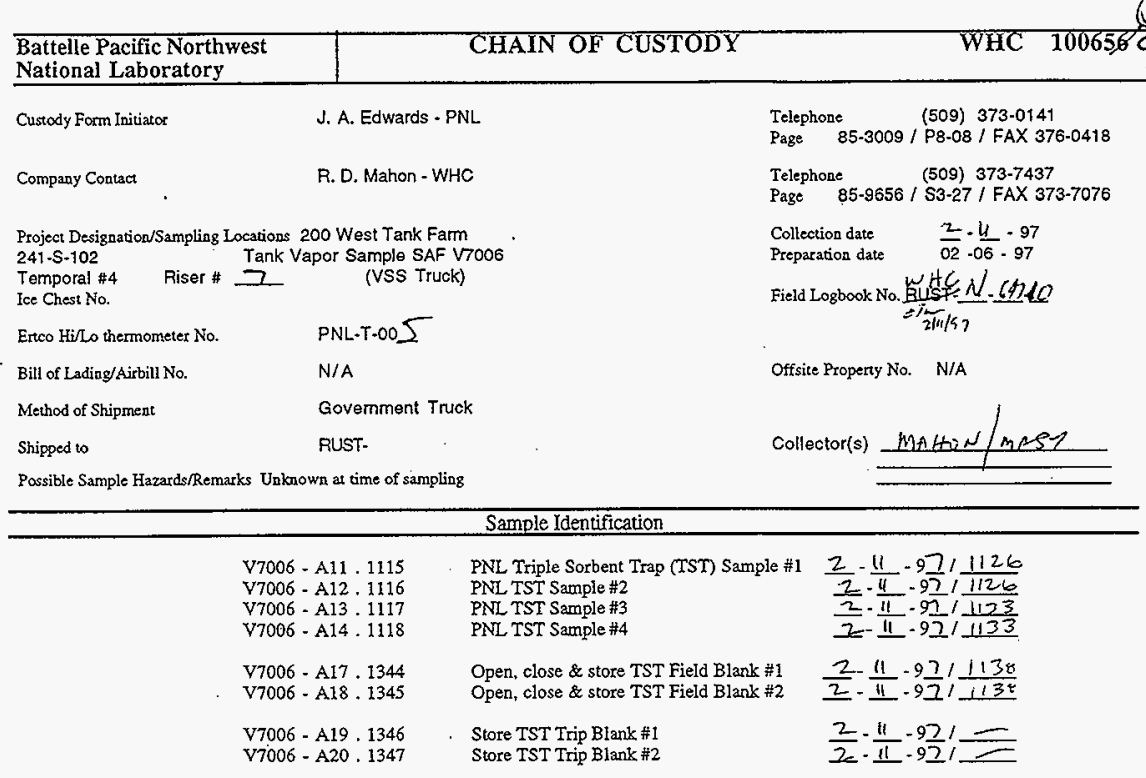

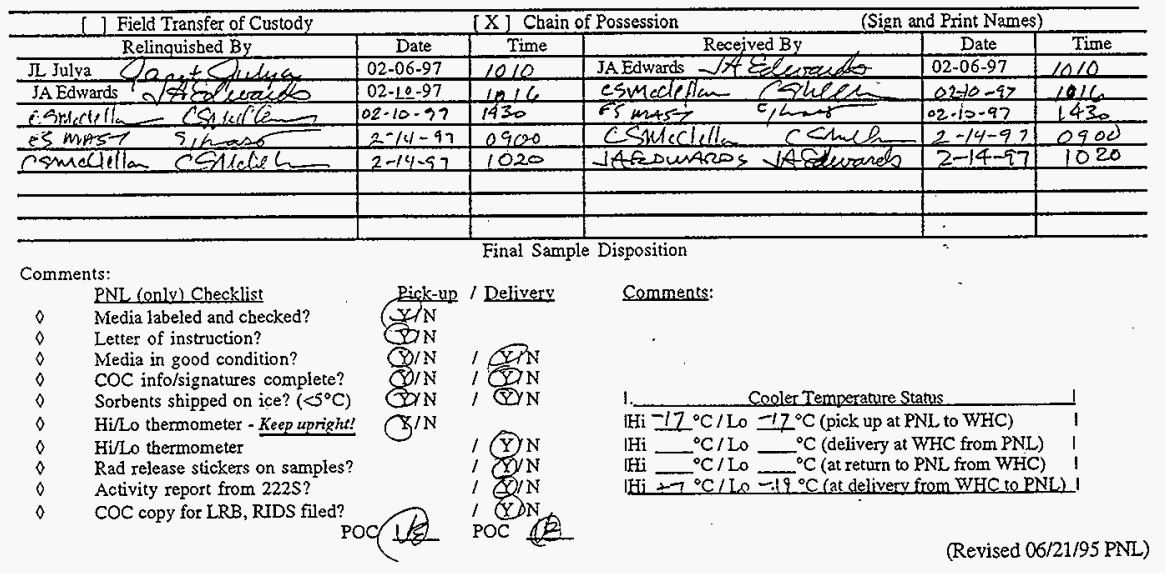




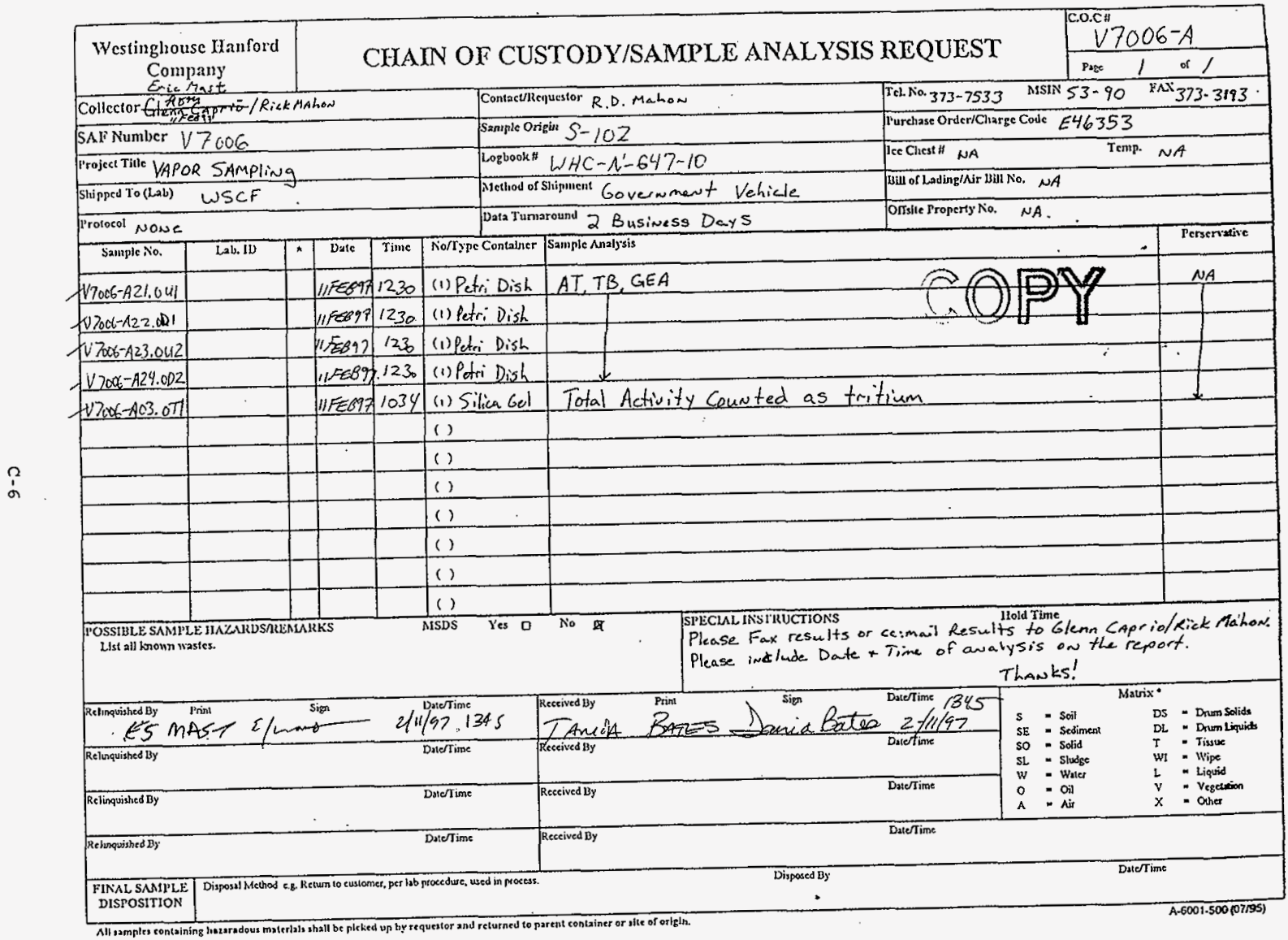




\section{DISTRIBUTION SHEET}

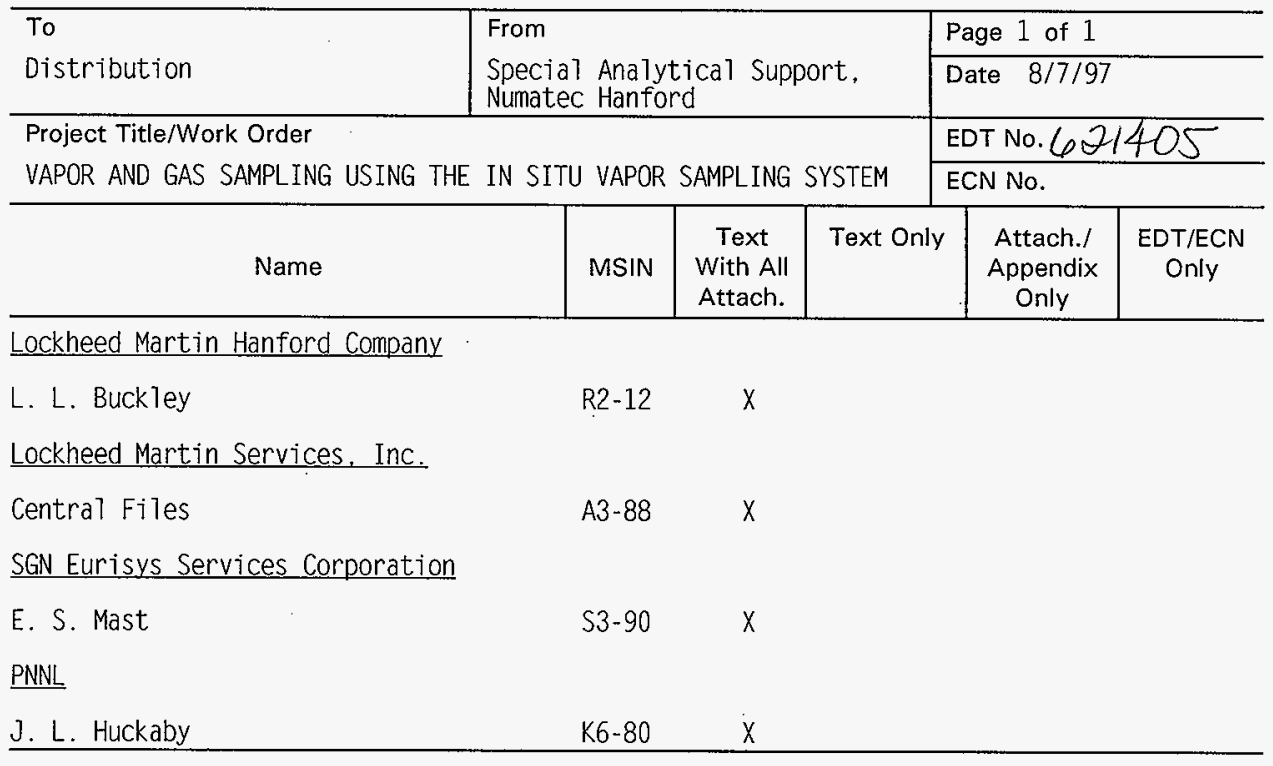

